\title{
Intake, growth and meat quality of steers given diets based on varying proportions of maize silage and grass silage
}

Article

Published Version

Juniper, D. T., Browne, E. M., Fisher, A., Bryant, M. J., Nute, G. and Beever, D. (2005) Intake, growth and meat quality of steers given diets based on varying proportions of maize silage and grass silage. Animal Science, 81. pp. 159-170. ISSN 1357-7298 Available at https://centaur.reading.ac.uk/4454/

It is advisable to refer to the publisher's version if you intend to cite from the work. See Guidance on citing.

Publisher: British Society of Animal Science

All outputs in CentAUR are protected by Intellectual Property Rights law, including copyright law. Copyright and IPR is retained by the creators or other copyright holders. Terms and conditions for use of this material are defined in the End User Agreement.

www.reading.ac.uk/centaur 
Central Archive at the University of Reading

Reading's research outputs online 


\title{
Intake, growth and meat quality of steers given diets based on varying proportions of maize silage and grass silage
}

\author{
D. T. Juniper ${ }^{1 \dagger}$, E. M. Browne ${ }^{1 \neq}$, A. V. Fisher ${ }^{2}$, M. J. Bryant ${ }^{1}$, G. R. Nute ${ }^{2}$ and D. E. Beever ${ }^{1}$ \\ ${ }^{1}$ Department of Agriculture, University of Reading, Earley Gate, Reading RG6 6AR, UK \\ ${ }^{2}$ Division of Farm Animal Science, Department of Clinical Veterinary Science, University of Bristol, Langford, Bristol BS40 5DU, UK \\ †E-mail: d.t.juniper@reading.ac.uk \\ fPresent address: Meat and Livestock Commission, PO Box 44, Winterhill House, Snowdon Drive, Milton Keynes MK6 1AX, UK.
}

\begin{abstract}
Simmental $\times$ Holstein-Friesian steers were offered four forage diets. These comprised grass silage (G); proportionately 0.67 grass silage, proportionately 0.33 maize silage (GGM); 0.33 grass silage, 0.67 maize silage (MMG); maize silage (M) from 424 (s.d. = 11.5) kg to slaughter at a minimum weight of $560 \mathrm{~kg}$. Forages were mixed and offered ad libitum. Steers were offered $2 \mathrm{~kg}$ of a concentrate daily, the concentrate being formulated such that all steers had similar crude protein intakes across dietary treatments. A sample of steers was slaughtered at the beginning of the experimental period to allow the calculation of the rate of gain of the carcass and its components. Carcass dissection of a sample of steers allowed the development of a prediction equation of carcass composition based on thoracic limb dissection of all carcasses. Forage dry matter intake and live-weight gain increased linearly as maize silage replaced grass silage in the forage mixture, resulting in improvements in food conversion ratio (all $\mathrm{P}=0.001$ ). Killing-out proportion increased with maize silage inclusion $(\mathrm{P}<0.001)$ but fat and conformation scores did not differ significantly between diets. However, increasing maize inclusion in the diet resulted in a greater weight $(\mathrm{P}=0.05)$ and proportion $(\mathrm{P}=0.008)$ of fat in the carcass, and significant increases in internal fat deposition. The inclusion of maize led to a progressive increase in the daily gains of carcass $(\mathrm{P}<0.001)$, and significant increases in the daily gains of both fat $(\mathrm{P}<0.001)$ and lean tissue $(\mathrm{P}<0.001)$. Fat colour was more yellow in cattle given diets $G$ and $G G M$ than diets $M M G$ and $M(P<0.001)$ and colour intensity was lower on diet $M$ than the other three diets $(\mathrm{P}<0.001)$. There were no significant differences in any aspects of eating quality between diets. Therefore, maize silage has the potential to reduce the time taken for finishing beef animals to achieve slaughter weight with no apparent detrimental effects on subsequent meat quality.
\end{abstract}

Keywords: carcass composition, grass silage, growth, maize silage, steers.

\section{Introduction}

In temperate areas with high rainfall and high seasonal productivity of Gramineae species, beef cattle are often finished on diets based on grass silage and a cereal-based concentrate. Yet the high cost of grass silage (Nix, 2003) and its variable nutritional quality, coupled with a need for expensive concentrate supplementation, has encouraged producers to look at alternative home grown forages. Forage crops like maize can deliver a number of advantages when included in ruminant livestock systems to complement grass. Yield benefits are one advantage; dry matter (DM) yields of maize silage are often good when grass silage yields are poor (Pahl et al., 1987). Other benefits include reduced growing and feeding costs, together with enhanced feeding value compared with grass silage (Bryan, 1990). Beef cattle can be finished on maize silage with only small quantities of protein supplementation (Browne et al., 1998) and can therefore form a useful alternative source of energy to grass silage for beef cattle.
While grass silage and maize silage are both used to finish cattle, direct comparisons between the two are scarce and very little research has been carried out using mixtures of these two forages offered to beef rather than dairy cattle. Despite this, mixtures of grass silage and maize silage are successfully used to finish beef cattle (Gerring, 1990). Previous work with dairy cows has shown significant positive effects on forage intake and performance when maize is included in rations containing grass silage (Izumi et al., 1982; Phipps et al., 1992; O’Mara et al., 1998). These studies also suggest that forage mixtures of maize silage and grass silage are capable of allowing milk production at levels similar to diets in which maize silage is the sole forage.

Many years ago workers in the UK demonstrated that performance of beef cattle offered maize-silage-based diets was either similar (Vadiveloo and Holmes, 1979) or better (Aston and Tayler, 1980) than cattle offered diets based on 


\section{Juniper, Browne, Fisher, Bryant, Nute and Beever}

grass silage. Since then maize silage quality has improved (Phipps, 1996) and recent work suggests that even maize silage containing very little starch can support better performance in beef cattle than moderate quality grass silage, and that a combination of both forages can improve intake and performance compared with grass silage (McCabe et al., 1995). Effects of forage source can also be extended to carcass traits. Some studies show no effect of silage type on killing-out proportion (Aston and Tayler, 1980; Forrest and Vanderstoep, 1985; McCabe et al., 1995) or level of carcass fatness (Aston and Tayler, 1980; McCabe et al., 1995), whilst other work has found maize-silage-finished cattle to have better killing-out proportions than those offered grass silage and to have fatter carcasses (Forrest, 1982).

This experiment aims to improve upon current information by comparing intake, physical performance and carcass composition of finishing beef cattle offered diets containing either grass silage or maize silage as the only forage component and diets in which these two silages have been mixed together in different proportions.

\section{Material and methods}

Dietary treatments

All diets were based on one of four forage combinations. The forage and concentrate components of each diet are listed in Table 1. The forage portion of each diet comprised either grass (diet G) or maize (diet M) silage offered separately or as a mixture. The grass silage and maize silage were mixed in the proportions $2: 1$ and vice versa (DM basis) : thus each silage comprised either 0.67 or 0.33 of the total forage DM in the diet (diets GGM and MMG respectively). Thorough mixing of the forages was performed using a small, selfpropelled mixer wagon (Data Ranger, American Calan Inc., USA), fitted with a weighing device (Weightronix Model 1015, Fairmont, USA) which recorded the weight of forage added to the revolving hopper and the weight of forage dispensed into the food bin.

Table 1 Constituent ingredients of forage mixtures comprised of grass silage and maize silage

Forage proportions

(g dry matter (DM) per kg total forage DM)

\begin{tabular}{lccc}
\cline { 2 - 4 } Diet & $\begin{array}{c}\text { Grass silage } \\
(\mathrm{G})\end{array}$ & $\begin{array}{c}\text { Maize silage } \\
(\mathrm{M})\end{array}$ & $\begin{array}{c}\text { Concentrate } \\
(\mathrm{kg} \mathrm{DM} \text { per day })\end{array}$ \\
\hline $\mathrm{G}$ & 1000 & 0 & $2 \cdot 0$ \\
GGM & 670 & 330 & $2 \cdot 0$ \\
MMG & 330 & 670 & $2 \cdot 0$ \\
M & 0 & 1000 & $2 \cdot 0$ \\
\hline \hline
\end{tabular}

Table 2 Ingredient composition of the concentrate supplements ( $\mathrm{kg} / \mathrm{t}$ fresh weight)

\begin{tabular}{lrrrr}
\hline \hline & \multicolumn{4}{c}{ Diet† } \\
\cline { 2 - 5 } & G & GGM & MMG & M \\
\hline Soya-bean meal & 160 & 250 & 330 & 420 \\
Rapeseed meal & 107 & 166 & 220 & 279 \\
Cracked wheat & 693 & 544 & 410 & 261 \\
Vitamins and minerals & 40 & 40 & 40 & 40 \\
\hline
\end{tabular}

$\dagger \mathrm{G}=1000 \mathrm{~g} / \mathrm{kg}$ grass; GGM = grass $670 \mathrm{~g} / \mathrm{kg}$, maize $330 \mathrm{~g} / \mathrm{kg}$; $M M G=$ maize $670 \mathrm{~g} / \mathrm{kg}$, grass $330 \mathrm{~g} / \mathrm{kg} ; \mathrm{M}=1000 \mathrm{~g} / \mathrm{kg}$ maize.
Each animal received $2 \mathrm{~kg}$ DM of concentrate daily offered as two equal meals morning and afternoon. Four different concentrates were formulated in an attempt to equalize dietary crude protein (CP) concentration whilst taking account of the protein content of the constituent forages and their different intake characteristics. All concentrates contained the same ingredients, namely cracked wheat, soya-bean meal and rapeseed meal, and a vitamin and mineral supplement (Table 2). Ratio of soya-bean meal to rapeseed meal was maintained at $60: 40$ in each ration. Target CP concentration for concentrates given diets $G$, GGM, MMG and M were 230, 270, 310 and $350 \mathrm{~g} \mathrm{CP}$ per $\mathrm{kg}$ $\mathrm{DM}$, respectively.

\section{Animals and experimental design}

The experiment included 56 bought-in Simmental cross Holstein-Friesian steers. Eight animals formed a pretreatment slaughter group (PTSG). The remaining 48 were housed in six pens, with each pen containing eight animals. Each pen was equipped with eight Calan-Broadbent electronic gates (Broadbent et al., 1970), with each gate being fixed to a wooden tombstone feeding barrier. Transponders were attached to neck collars and activated only one feeding gate in each pen. The cattle lay on rubber mats in individual cubicles. No bedding was provided.

Prior to the start of the study animals were blocked according to live weight, with each block of animals housed in a separate straw bedded pen. Therefore, all cattle in the same pen were of a similar live weight. Blocks 1, 3, 4 and 6 contained 10 animals whereas blocks 2 and 5 contained eight. Two animals within each block were randomly allocated to each dietary treatment and two cattle from blocks 1, 3, 4 and 6 formed the PTSG.

To maintain constant start live weights throughout the trial each block of cattle were put into experimental pens progressively, such that block 1 started on the experiment 12 weeks before block 6 . As blocks 1, 3, 4 and 6 entered the study the two animals from each block that formed the PTSG were slaughtered. Mean start LW was 424 (s.d. 11.5) kg.

\section{Crop management and harvest}

The grass silage was made from a semi-permanent, predominantly perennial ryegrass (Lolium perenne cv.) pasture harvested between 26 May and 6 June. During the growing season two applications of artificial fertilizer were applied. Between 27 and 29 February $68 \mathrm{~kg} / \mathrm{ha}$ of nitrogen (N) was applied and an application of 70, 28 and $49 \mathrm{~kg} / \mathrm{ha}$ of $N$, phosphorus $(P)$ and potassium $(K)$, respectively, was made between 7 and 10 April.

The crop was mown with a Vicon (KM 3000 HPC) mowerconditioner and allowed to wilt for $24 \mathrm{~h}$ before being rowed into swathes for harvesting by a self-propelled precision chop forage harvester (New Holland 2205). Weather conditions during grass harvest made it necessary to apply a forage additive to some of the grass when rain fell on the crop after mowing. The additive was Add-saFe (BP Nutrition Ltd, Cheshire), which contained ammonium formate (proportionately 0.17 ), ammonium propionate (0.05), formic acid $(0.38)$ and propionic acid $(0 \cdot 11)$ and was applied at a rate of $2 \mathrm{l} / \mathrm{t}$ fresh material. 


\section{Grass silage : maize silage ratios for beef steers}

The maize crop (variety Helix) was precision-drilled at a rate of 108000 seeds per ha on 7 and 9 May into fields in which maize had been grown during the previous year. Seventy kg $\mathrm{N}$ per ha and $45 \mathrm{~kg} \mathrm{~K}$ per ha was applied to the ploughed land before drilling and $15 \mathrm{~kg} \mathrm{~N}$ and $65 \mathrm{~kg} \mathrm{P}$ per ha was applied at drilling. Fields were sprayed either once or twice during the season with atrazine and bromotril at a rate of 2.0 and $0.75 \mathrm{l} /$ ha, respectively, and 1.0 and $1.4 \mathrm{l} / \mathrm{ha}$, respectively, if a second application was required.

Three fields were harvested on the 6 and 7 October, totalling 16 ha. The crop was ensiled immediately without any additive and rolled thoroughly before being sheeted and covered with tyres to ensure exclusion of air.

\section{Measurements}

Intake and live weight. All cattle were allocated to the dietary treatments 14 days prior to recording intake and LW measurement to allow for diet adaptation. Forage was offered ad libitum through the electronic feeding gates, maintaining refusals at between 100 and $150 \mathrm{~g} / \mathrm{kg} \mathrm{DM}$ of previous daily intake.

During the experiment all animals were weighed before feeding. At the start and end of the experiment LW was recorded on 2 days consecutively. Initially the cattle were weighed every 2 weeks but as they approached the target slaughter weight this interval was reduced to 1 week. Liveweight gain (LWG) was calculated by difference using the mean of the two initial and final values.

Food sampling and chemical analyses. Forage offered was sampled three times a week and concentrates twice a week. Oven DM of forages and concentrates were determined three times a week and food refusals twice weekly. Forage samples were frozen and combined to form a bulk sample every 12 weeks.

Oven DM content was determined by drying samples in a forced draught oven at $100^{\circ} \mathrm{C}$ for $24 \mathrm{~h}$. To account for DM of fresh silage lost in the form of volatile components during oven drying, the equation reported by Porter et al. (1984) was employed after determination of the concentrations of volatile fatty acids. Organic matter (OM) was obtained by difference after ashing the dried sample in a muffle furnace at $550^{\circ} \mathrm{C}$ for $16 \mathrm{~h}$. Neutral-detergent fibre (NDF) contents were determined by ANKOM-Fibre analyser 200 (ANKOMTechnology, Fairpoint, NY, USA) by procedures described by Ministry of Agriculture, Fisheries and Food (MAFF, 1993) using sodium dodecyl sulphate and alpha amylase solutions and corrected for residual ash (MAFF, 1986). Starch was determined by polarimetry (MAFF, 1982) with random samples analysed using the enzyme technique (MacRae and Armstrong, 1968) to verify the calibration of the polarimeter. $\mathrm{N}$ content was measured by the Kjeldahl technique and water-soluble carbohydrate (WSC) content was measured spectrophotometrically.

\section{Slaughter}

All cattle were slaughtered at the Division of Food Animal Science at Bristol University, having reached a minimum LW of $560 \mathrm{~kg}$. Final LW was calculated as the mean of two weights recorded on the day of, and the day prior to, transportation of cattle to the abattoir. These measurements included one day when the cattle were still housed in their experimental pens and one day when they were housed in a large straw pen to improve hide cleanliness. During housing in the strawed pen an approximately equal mixture of grass and maize silage was offered to the cattle.

Groups of between two and five cattle were transported to Bristol on the day prior to slaughter. On arrival, they were housed in a lairage pen bedded with straw and offered a grass/ maize silage mixture and fresh water. They were not mixed with other cattle and were slaughtered approximately $20 \mathrm{~h}$ after arrival at the lairage by captive bolt and exsanguination. Carcasses were dressed by removal of the head, tail, feet and the abdominal and thoracic viscera. Kidney knob and channel fat was left inside the carcass and no other fat depots were trimmed before each carcass side was weighed. All carcasses were visually graded for conformation and external fat cover. Two classification scales were used, the EU scheme (European Economic Community (EEC), 1981) and the 15-point scale (de Boer et al., 1974). In the UK adaptation of the EU scheme (commonly referred to as the EUROP scheme, the term used in this paper) conformation classes $\mathrm{U}, \mathrm{O}$ and $\mathrm{P}$ are subdivided into + and - subclasses and fatness classes 4 and 5 are similarly subdivided into low (L) and high $(\mathrm{H})$ subclasses. Killing-out proportion (g per $100 \mathrm{~g}$ ) was calculated as $100 \times$ carcass weight/final live weight.

\section{Carcass dissection}

The left side from a total of 20 carcasses, four from the PTSG and four from each of the dietary treatments, underwent full dissection and the relationship between the tissue content of the side and the proximal thoracic limb was quantified using regression analysis to formulate a prediction equation that could be applied to the partially dissected sides from the remaining 36 animals. Sides were prepared, quartered and anatomically jointed based on the method of Bergstrom and Williams (1980). Briefly, preparation of the side involved the removal and recording of internal fat depots, removal and recording of the muscles associated with the male genital organs, diaphragm, and the $m$. sternocephalicus, and the removal and recording of the remnants of the large blood vessels and spinal cord.

Tissues were separated out and recorded, according to the EEC standard method for beef (Bergstrom and Williams, 1980) to determine the total lean, fat and bone content of the whole side. Subcutaneous fat depth was measured over the third lumbar vertebra and last rib and the depth of the longissimus thoracis et lumborum ( $L T L)$ was measured over the third rib and third lumbar vertebra.

\section{Assessment of meat quality}

The colour of the subcutaneous fat covering the loin area and of the longissimus muscle exposed by a cross-sectional cut at the last rib was assessed $48 \mathrm{~h}$ post mortem using a Minolta Chromameter 200. This involved a measure of light/ darkness, defined as $L^{*}$, a measure of redness/greenness, defined as $a^{*}$, and a measure of yellowness/blueness, defined as $b^{*}$ (Honikel, 1998). The hue angle (HUE), a measure of colour, and colour saturation (SAT), a measure of 


\section{Juniper, Browne, Fisher, Bryant, Nute and Beever}

colour intensity, were determined from the values $a^{*}$ and $b^{*}$ by the following equations:

$$
\begin{aligned}
& \text { HUE }=\arctan b^{\star} / a^{*} \\
& \text { SAT }=\left[\left(a^{\star}\right)^{2}+\left(b^{\star}\right)^{2}\right]^{0.5} .
\end{aligned}
$$

In addition, $\mathrm{pH}$ was also measured $48 \mathrm{~h}$ post mortem in the LTL between the 10th and 11th ribs and at the third lumbar vertebra using a Testo $230 \mathrm{pH}$ probe.

\section{Sensory evaluation}

Sensory evaluation was carried out as described by Vatansever et al. (2000) on a section of the longissimus thoracis taken from the 10th to 12th rib section and aged for 12 days prior to freezing. Loins were thawed for $24 \mathrm{~h}$ prior to evaluation. On the morning of evaluation, loins were trimmed level at the ends and cut into $1.9 \mathrm{~cm}$ thick steaks. Steaks were grilled under pre-heated conventional Tricity low level grills, being turned every three minutes until the internal temperature of the steak reached $74^{\circ} \mathrm{C}$. Cooked samples were further prepared by the removal of all visible fat, connective tissue and edges of muscle to produce a near uniform cuboid of meat.

Ten assessors, who had been selected and trained in accordance with British Standards Institution (1993), performed the sensory assessments under red light in a purpose-built room. Assessors used direct entry into a computerized sensory assessment program to record results. Each assessor was given a list of sensory descriptors (see Table 11) and a definition to these words that had been agreed to by the assessors at previous training sessions. Apart from toughness and juiciness, all scales were intensity related where the left-hand anchor point was 'nil' and the right-hand anchor point was marked 'extreme'. Toughness had anchor points of nil (tender) and extreme (tough), juiciness was marked nil (dry) and extreme (juicy). Individual definitions for the flavour descriptors were also given, where beef flavour was defined as the amount of cooked beef flavour, fatty/greasy was the taste associated with fresh oil and fat, livery was defined as the flavour associated with fresh liver, metallic was defined as a tangy metallic taste and bitter was defined as the taste on the tongue associated with caffeine/quinine. An hedonic attribute, overall liking, was also included and the anchor points for this attribute was poor to good. This scale serves as an indication of preference but comes from a small set of trained sensory assessors and therefore cannot indicate consumer preference, which would typically require a panel size of at least 100 persons.

Assessors were asked to rate samples for each attribute by marking a point on a $100-\mathrm{mm}$ unstructured line scale with anchor points at each end. At each session assessors were presented with four samples comprising one from each of the treatments described earlier. These were presented in randomized orders to reduce order effects. In total there were 12 panels, which were attended by the same assessors throughout the experiment

\section{Statistical analysis}

Statistically significant differences between individual treatments for variables relating to animal physical performance, carcass gains and composition, and meat quality were determined by analysis of variance using the general linear model procedure (GLM). The data set contained 48 observations for each variable and the model consisted of diet ( 3 d.f.) and pen ( 5 d.f.). Start weight and finish weight were used as covariate terms in the statistical analysis. Results are presented as least-square means (LSM) with the standard error of the difference (s.e.d.).

Statistical differences in the sensory evaluation data were determined by analysis of variance using a model in which diet and assessors were factors and panels were treated as a 'block' structure. Results are presented as panel mean scores with s.e.d.

\section{Results}

Forage and concentrate composition

Chemical composition and nutritive value of the grass silage and maize silage is shown in Table 3. The DM concentration of the grass silage was lower and more variable than the maize silage and tended to decline as the trial progressed. Due to the higher ash content of the grass silage, it contained less organic matter than the maize silage. Neutral-detergent fibre and water-soluble carbohydrate content of the grass silage was higher than the maize silage, which had a starch content of $301 \mathrm{~g} / \mathrm{kg}$ DM. CP content of the grass silage was disappointingly low (120 g/kg DM) but still higher than the maize silage.

Both silages were well fermented, as indicated by their low ammonia- $\mathrm{N}$ levels and $\mathrm{pH}$ values. However, the grass silage had a higher concentration of fermentation acids than the maize silage

The mean CP content of the concentrates for diets $G$, GGM, MMG and M were 225, 269, 313 and $362 \mathrm{~g} / \mathrm{kg} \mathrm{DM}$, respectively. Increasing the $\mathrm{CP}$ content of the concentrates by replacing cracked wheat with soya-bean meal and rapeseed meal also increased the NDF concentration but reduced the content of organic matter and starch in the blend.

\section{DM intake and animal performance}

Dry matter intake (DMI) and physical performance of cattle is given in Table 4. Forage DMI increased linearly $(P=0.001)$ as maize silage replaced grass silage in the forage mixture. Total DM intake was related to the proportion of maize silage in the diet and forage starch concentration by the following equations:

$$
\begin{aligned}
& \text { total DMI ( } \mathrm{g} / \mathrm{kg} \text { live weight })=2 \cdot 768 x+16 \cdot 874 \\
& \left(R^{2}=0.542\right) \quad(P<0.001) \\
& x=\text { proportion of maize silage in the diet; } \\
& \text { total DMI ( } \mathrm{g} / \mathrm{kg} \text { live weight })=0.009 x+16.937 \\
& \left(R^{2}=0.539\right) \quad(P<0.001) \\
& x=\text { starch concentration of the silage }(\mathrm{g} / \mathrm{kg} \mathrm{DM}) \text {. }
\end{aligned}
$$

Differences in forage and total DM intake were significant between all diets with the exception of $G$ and GGM 


\section{Grass silage : maize silage ratios for beef steers}

Table 3 Chemical composition and nutritive value of grass silage and maize silage ( $g / k g$ corrected dry matter (DM), unless otherwise stated)

\begin{tabular}{|c|c|c|c|c|}
\hline & \multicolumn{4}{|c|}{ Silage } \\
\hline & \multicolumn{2}{|c|}{ Grass } & \multicolumn{2}{|c|}{ Maize } \\
\hline & Mean & s.e. & Mean & s.e. \\
\hline Dry matter (g/kg fresh weight)† & 265 & $12 \cdot 0$ & 332 & $5 \cdot 6$ \\
\hline \multicolumn{5}{|l|}{ DM composition } \\
\hline Organic matter & 926 & $2 \cdot 7$ & 957 & $1 \cdot 1$ \\
\hline Starch & ND & - & 301 & $15 \cdot 6$ \\
\hline Water-soluble carbohydrates & 25 & $0 \cdot 3$ & 14 & $0 \cdot 6$ \\
\hline Total nitrogen & $19 \cdot 2$ & $0 \cdot 4$ & $13 \cdot 4$ & $0 \cdot 2$ \\
\hline Crude protein & 120 & $2 \cdot 5$ & 84 & $1 \cdot 5$ \\
\hline Metabolizable energy (MJ/kg DM)‡ & $10 \cdot 4$ & 0.05 & $11 \cdot 3$ & 0.02 \\
\hline \multicolumn{5}{|l|}{ Fermentation characteristics } \\
\hline Lactic acid & 93 & $8 \cdot 16$ & 51 & $2 \cdot 10$ \\
\hline Acetic acid & 24 & $1 \cdot 74$ & 19 & 1.65 \\
\hline Butyric acid & 3 & $1 \cdot 63$ & 0 & 0 \\
\hline Ethanol & 10 & 0.73 & 12 & 0.62 \\
\hline Ammonia N (g/kg total $\mathrm{N})$ & 57 & $6 \cdot 51$ & 68 & $5 \cdot 90$ \\
\hline $\mathrm{pH}$ & $3 \cdot 83$ & 0.03 & $3 \cdot 77$ & 0.03 \\
\hline
\end{tabular}

ND = not determined.

† DM content of forages corrected for loss of volatiles (Porter et al., 1984).

¥ Maize silage ME calculated from neutral-detergent cellulose [digestible organic matter in DM] (Agricultural and Food Research Council, 1995); grass silage ME calculated from organic matter digestibility (OMD) predicted using near infrared reflectance (NIR) spectroscopy (ADAS/ DANI/SAC/UKASTA, 1993).

$(P=0.075)$, and $M M G$ and $\mathrm{M}(P=0.237)$. Total replacement of grass silage with maize silage increased forage DM intake by proportionately 0.23 , or $1.43 \mathrm{~kg} \mathrm{DM}$ per day, which was equivalent to $2 \cdot 8 \mathrm{~g} / \mathrm{kg}$ live weight. Since a uniform quantity of concentrates was given with each forage mixture, inclusion of maize silage also increased the proportion of forage in the total ration from $76 \mathrm{~g}$ per $100 \mathrm{~g}$ in diet $\mathrm{G}$ to 77,79 and $79 \mathrm{~g}$ per $100 \mathrm{~g}$ in diets $\mathrm{GGM}, \mathrm{MMG}$ and $\mathrm{M}$, respectively.

Daily LWG similarly showed a linear increase when grass silage was replaced with maize silage. LWG can be represented by the equations:
LWG $(\mathrm{kg} /$ day $)=0.343 x+0.938 \quad\left(R^{2}=0.524\right) \quad(P<0.001)$ $x=$ proportion of maize silage in the diet;

$\operatorname{LWG}(\mathrm{kg} /$ day $)=0.001 x+0.948 \quad\left(R^{2}=0.510\right) \quad(P<0.001)$ $x=$ starch concentration of the silage $(g / \mathrm{kg} \mathrm{DM})$.

Differences between diets were significant except for the comparisons between GGM and MMG, and MMG and $M$. Differences in food conversion ratio between the three diets containing maize silage were not significant, but diets containing higher proportions of maize silage (MMG and

Table 4 Dry matter (DM) intake and physical performance of beef steers given forage mixtures of grass silage and maize silage

\begin{tabular}{|c|c|c|c|c|c|c|c|c|}
\hline & \multicolumn{4}{|c|}{ Diet† } & \multirow{2}{*}{ s.e.d. } & \multicolumn{3}{|c|}{ Significance } \\
\hline & $\mathrm{G}$ & GGM & MMG & $M$ & & Diet & Linear & Quadratic \\
\hline Silage & $6 \cdot 33$ & $6 \cdot 82$ & $7 \cdot 39$ & $7 \cdot 76$ & $0 \cdot 195$ & 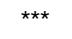 & $\star \star \star$ & $\star \star$ \\
\hline Concentrates & 1.99 & $2 \cdot 00$ & $2 \cdot 01$ & $2 \cdot 01$ & & & & \\
\hline Total & $8 \cdot 32$ & $8 \cdot 82$ & $9 \cdot 40$ & $9 \cdot 77$ & $0 \cdot 195$ & 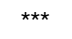 & $\star \star \star$ & ** \\
\hline $\begin{array}{l}\text { g DMI per kg live weight } \\
\text { Physical performance }\end{array}$ & $16 \cdot 9$ & $17 \cdot 8$ & $18 \cdot 7$ & $19 \cdot 7$ & $0 \cdot 40$ & $\star \star \star \star ~$ & $\star \star \star \star ~$ & ** \\
\hline Start live weight $(\mathrm{kg})$ & 420 & 423 & 433 & 421 & $4 \cdot 2$ & * & & \\
\hline Final live weight (kg) & 566 & 569 & 571 & 574 & $2 \cdot 7$ & * & & \\
\hline Daily live-weight gain (DLWG, kg/day) & 0.920 & $1 \cdot 070$ & $1 \cdot 186$ & $1 \cdot 262$ & 0.049 & 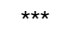 & 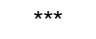 & ** \\
\hline Food conversion ratio & $9 \cdot 12$ & $8 \cdot 32$ & $8 \cdot 03$ & $7 \cdot 78$ & $0 \cdot 317$ & $\star \star \star ~$ & $\star \star \star ~$ & * \\
\hline Partial food conversion ratio§ & $6 \cdot 94$ & $6 \cdot 42$ & $6 \cdot 30$ & $6 \cdot 17$ & 0.239 & * & ** & $\|$ \\
\hline
\end{tabular}

$\dagger \mathrm{G}=1000 \mathrm{~g} / \mathrm{kg}$ grass; GGM = grass $670 \mathrm{~g} / \mathrm{kg}$, maize $330 \mathrm{~g} / \mathrm{kg} ; \mathrm{MMG}=$ maize $670 \mathrm{~g} / \mathrm{kg}$, grass $330 \mathrm{~g} / \mathrm{kg} ; \mathrm{M}=1000 \mathrm{~g} / \mathrm{kg}$ maize.

‡ Food conversion ratio (kg DMI per kg DLWG).

$\S$ Partial food conversion ratio ( $\mathrm{kg}$ forage DMI per kg DLWG).

\| Approaching significance $(P<0 \cdot 1)$. 


\section{Juniper, Browne, Fisher, Bryant, Nute and Beever}

Table 5 Nutrient concentration of diets containing mixtures of grass silage and maize silage (g/kg dry matter (DM) intake, unless otherwise stated)

\begin{tabular}{|c|c|c|c|c|c|c|}
\hline & \multicolumn{4}{|c|}{ Diet† } & \multirow[b]{2}{*}{ s.e.d. } & \multirow[b]{2}{*}{ Significance } \\
\hline & $\mathrm{G}$ & GGM & MMG & M & & \\
\hline Crude protein & 145 & 144 & 144 & 141 & $1 \cdot 01$ & 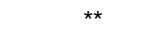 \\
\hline Metabolizable energy (MJ/kg DM) & $11 \cdot 13$ & $11 \cdot 20$ & $11 \cdot 28$ & $11 \cdot 44$ & 0.007 & *** \\
\hline Starch & 115 & 162 & 210 & 289 & $1 \cdot 2$ & *** \\
\hline Neutral-detergent fibre & 441 & 421 & 400 & 358 & $1 \cdot 3$ & 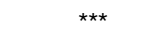 \\
\hline
\end{tabular}

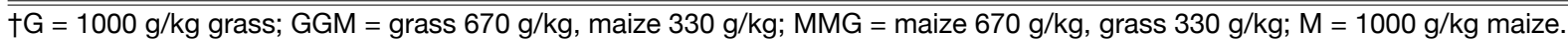

M) had significantly better conversion ratios than diet $G$ $(P<0 \cdot 001)$

\section{Nutrient intake}

Dietary concentration of metabolizable energy (ME), CP, starch and NDF is detailed in Table 5. ME concentration of the forages was assumed to equal the values determined from in vivo determination of $\mathrm{ME}$ using $\mathrm{ME}=0.84 \times$ digestible energy (Browne, 2000), whilst ME of the concentrates was calculated from their composition using standard tables (MAFF, 1992). Protein concentration was numerically similar for all four diets $(P=0.003)$ although it was slightly lower in diet $\mathrm{M}$ compared with those diets containing grass silage. Both dietary energy and starch concentration was positively related to the amount of maize silage in the ration. In contrast, fibre concentration showed a gradual decline when the grass silage was increasingly replaced by maize silage.

Daily intake of total $\mathrm{N}$ and $\mathrm{ME}$ is shown in Figure 1 and total intake of starch and NDF is shown in Figure 2. The positive effect of maize silage inclusion in the forage mixture on total DM intake was reflected in increased energy and total $N$ (hence $\mathrm{CP})$ intake $(P=0.001)$. On average, each increment of maize silage inclusion increased ME intake by $6.4 \mathrm{MJ} /$ day and total $\mathrm{N}$ intake by $9.1 \mathrm{~g} /$ day. Likewise starch intake increased linearly as maize silage was added to the diet and

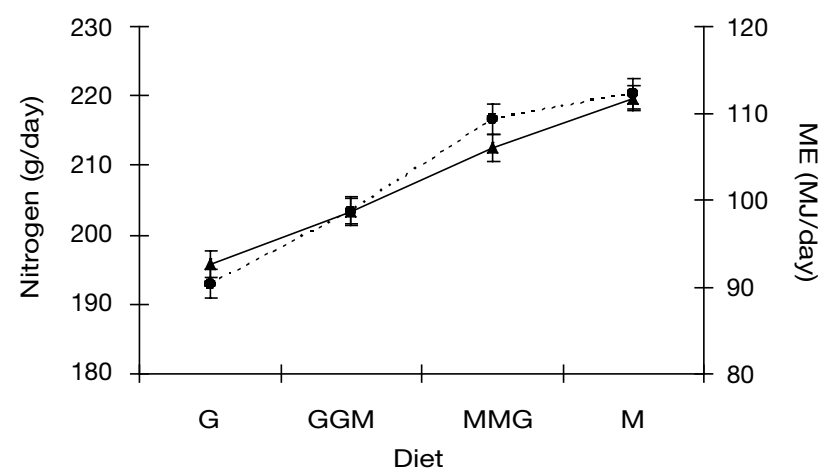

Figure 1 Daily intake of metabolizable energy (ME, $\mathbf{\Delta})$ and nitrogen (O) of beef steers given different forage mixtures ( $\mathrm{G}=1000 \mathrm{~g} / \mathrm{kg}$ grass; GGM = grass $670 \mathrm{~g} / \mathrm{kg}$, maize $330 \mathrm{~g} / \mathrm{kg}$; MMG = maize 670 $\mathrm{g} / \mathrm{kg}$, grass $330 \mathrm{~g} / \mathrm{kg} ; \mathrm{M}=1000 \mathrm{~g} / \mathrm{kg}$ maize). resulted in starch intake increasing by approximately $600 \mathrm{~g} /$ day at each increment of maize silage inclusion. NDF intake was less affected by the relative amount of grass silage and maize silage in the mixture, although daily intake of fibre in diet $M$ was slightly lower than diets GGM and MMG $(P=0.029)$.

LWG was positively related to ME intake with a large proportion of variation in gain being associated with ME intake:

$$
\begin{gathered}
\text { LWG }(\mathrm{kg} / \text { day })=-0.0003 x^{2}+0.0819 x-3.9813 \\
\left(R^{2}=0.772\right) \quad(P<0.001) \\
\text { where } x=\text { ME intake }(\mathrm{MJ} / \text { day }) .
\end{gathered}
$$

\section{Slaughter results}

Slaughter results and carcass quality are described in Table 6. Carcass weight increased between diets $G$ and $M$ mainly as a consequence of the better killing-out proportion of cattle on diets containing maize silage. Killing-out proportion was significantly $(P<0.001)$ higher for the diet containing $330 \mathrm{~g} /$ $\mathrm{kg}$ compared with $0 \mathrm{~g} / \mathrm{kg}$ maize and for $1000 \mathrm{~g} / \mathrm{kg}$ compared with $330 \mathrm{~g} / \mathrm{kg}$ maize.

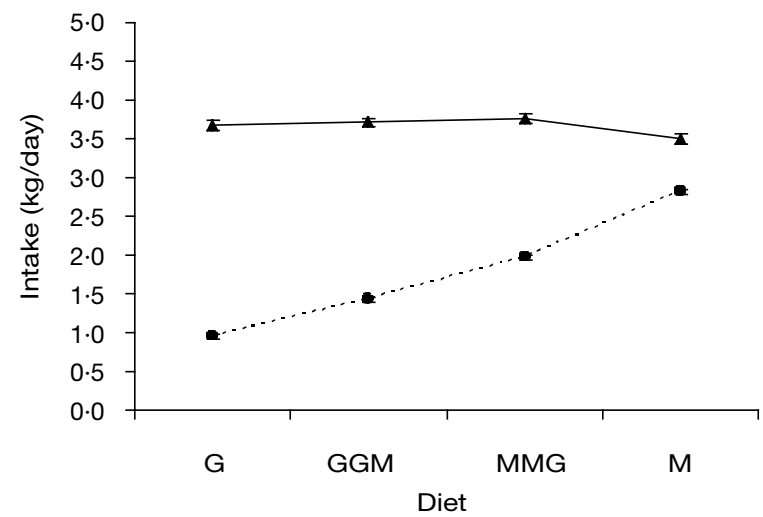

Figure 2 Daily intake of starch $(\mathbf{0})$ and neutral-detergent fibre $(\mathbf{\Delta})$ of beef steers given different forage mixtures $(G=1000 \mathrm{~g} / \mathrm{kg}$ grass; $\mathrm{GGM}=$ grass $670 \mathrm{~g} / \mathrm{kg}$, maize $330 \mathrm{~g} / \mathrm{kg} ; \mathrm{MMG}=$ maize $670 \mathrm{~g} / \mathrm{kg}$, grass $330 \mathrm{~g} / \mathrm{kg} ; \mathrm{M}=1000 \mathrm{~g} / \mathrm{kg}$ maize). 


\section{Grass silage : maize silage ratios for beef steers}

Table 6 Slaughter results and fat and conformation scores of finished steers that had been given mixtures of grass silage and maize silage

\begin{tabular}{|c|c|c|c|c|c|c|c|c|}
\hline & \multicolumn{4}{|c|}{ Diet† } & \multirow{2}{*}{ s.e.d. } & \multicolumn{3}{|c|}{ Significance } \\
\hline & $\mathrm{G}$ & GGM & MMG & M & & Diet & Linear & Quadratic \\
\hline Carcass weight (kg) & $314 \cdot 5$ & $318 \cdot 8$ & $320 \cdot 1$ & $321 \cdot 9$ & $1 \cdot 93$ & $\star \star \star$ & $\star \star \star$ & * \\
\hline Killing-out proportion (g per 100 g) & $55 \cdot 18$ & 55.94 & $56 \cdot 18$ & $56 \cdot 49$ & $0 \cdot 322$ & $\star \star \star *$ & ** & * \\
\hline \multicolumn{9}{|l|}{ Carcass quality } \\
\hline EUROP & $81 \cdot 76$ & $81 \cdot 89$ & $84 \cdot 48$ & $79 \cdot 28$ & $5 \cdot 722$ & & & \\
\hline 15 point & $7 \cdot 460$ & $7 \cdot 509$ & $7 \cdot 587$ & $7 \cdot 578$ & $0 \cdot 740$ & & & \\
\hline \multicolumn{9}{|l|}{ Conformation score } \\
\hline EUROP§ & $70 \cdot 64$ & $76 \cdot 13$ & $74 \cdot 26$ & $76 \cdot 67$ & $8 \cdot 344$ & & & \\
\hline 15 point & $7 \cdot 814$ & $8 \cdot 186$ & $7 \cdot 479$ & $7 \cdot 835$ & 0.516 & & & \\
\hline
\end{tabular}

†G = $1000 \mathrm{~g} / \mathrm{kg}$ grass; GGM = grass $670 \mathrm{~g} / \mathrm{kg}$, maize $330 \mathrm{~g} / \mathrm{kg} ; \mathrm{MMG}=$ maize $670 \mathrm{~g} / \mathrm{kg}$, grass $330 \mathrm{~g} / \mathrm{kg} ; \mathrm{M}=1000 \mathrm{~g} / \mathrm{kg}$ maize.

$\ddagger$ Based on fat score $20=1,45=2,65=3,90=4 \mathrm{~L}$.

$\S$ Based on $20=\mathrm{P}, 30=-\mathrm{O}, 55=\mathrm{O}+, 85=\mathrm{R}, 115=-\mathrm{U}$.

In terms of fat and conformation scores, carcass quality was similar across all the diets. Conversion of the numerical carcass scores to commercial beef carcass classification equates to an overall EUROP classification of R4L, the modal class for conformation/fatness combined scores in the United Kingdom.

Internal fat deposition and calculated rate of deposition are shown in Table 7 . The rate of gain of internal fat in the kidney depot (kidney knob) increased significantly $(P<0.004)$ with ascending maize inclusion in the diets. A similar linear response was observed for deposition and rate of deposition in the cod/udder depot $(P=0.001$ and $\mathrm{P}<0.001$, respectively). However, although there was a numerical trend for maize to increase rates there was no significant effect on the deposition of fat in the thoracic and channel fat depots.

Carcass composition. The relationship between the proximal thoracic limb tissue content and the whole side tissue content was best expressed as:

$$
\text { fat content }=-7437+7 \cdot 63 x+0 \cdot 421 y-2 \cdot 45 z
$$$$
\left(R^{2}=0.930 ; \quad P<0.001\right)
$$

$$
\begin{aligned}
& \text { lean tissue content }=18856+6 \cdot 93 x+0 \cdot 181 y-2 \cdot 14 z \\
& \qquad\left(R^{2}=0.935 ; \quad P<0 \cdot 001\right) \\
& \text { bone content }=15087+2 \cdot 68 x+0.0622 y-2 \cdot 14 z \\
& \left(R^{2}=0.465 ; \quad P<0.010\right) ;
\end{aligned}
$$

where $x=$ proximal thoracic limb fat, lean and bone content (g) for the three equations respectively, $y=$ weight of whole prepared side $(\mathrm{g})$, and $z=$ weight of proximal thoracic limb (g).

The predicted carcass composition is shown in Table 8 and shows that the carcasses of animals that had received diets MMG and M contained more fat than those that had received grass only $(P=0 \cdot 05)$. There were no differences between diets in the yield of lean tissue. However, when tissues were expressed as proportions of the total carcass, then the carcasses of animals that had received diets MMG and $\mathrm{M}$ contained proportionally more fat $(P<0.05)$ and

\begin{tabular}{|c|c|c|c|c|c|c|c|c|}
\hline & \multicolumn{4}{|c|}{ Diet† } & \multirow{2}{*}{ s.e.d. } & \multicolumn{3}{|c|}{ Significance } \\
\hline & $\mathrm{G}$ & GGM & MMG & $M$ & & Diet & Linear & Quadratic \\
\hline Kidney knob (g) & 5999 & 6854 & 7009 & 7693 & $626 \cdot 6$ & $\ddagger$ & $\ddagger$ & $\ddagger$ \\
\hline Kidney knob gain per day (g) & $20 \cdot 0$ & $28 \cdot 8$ & $32 \cdot 0$ & $41 \cdot 8$ & $4 \cdot 6$ & 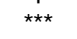 & ** & $\star \star *$ \\
\hline Thoracic (g) & 119 & 185 & 219 & 236 & $71 \cdot 0$ & & & \\
\hline Thoracic gain per day (g) & $0 \cdot 39$ & 0.57 & 0.89 & $1 \cdot 03$ & 0.54 & & & \\
\hline Channel (g) & 567 & 568 & 531 & 556 & $83 \cdot 7$ & & & \\
\hline Channel gain per day $(\mathrm{g})$ & $1 \cdot 9$ & $2 \cdot 3$ & $2 \cdot 3$ & $2 \cdot 8$ & 0.5 & & & \\
\hline Cod/udder (g) & 2796 & 3133 & 3483 & 3603 & $223 \cdot 7$ & ** & $\star \star \star$ & \\
\hline Cod/udder gain per day (g) & 8.9 & $12 \cdot 8$ & $16 \cdot 6$ & $19 \cdot 8$ & $1 \cdot 7$ & $\star \star \star \star$ & 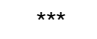 & * \\
\hline
\end{tabular}
proportionally less lean $(P<0.05)$ than $\mathrm{G}$.

Carcass and tissue gains. Carcass and tissue gains, based on comparisons between the PTSG and treatment groups,

Table 7 Internal fat deposition of finished steers that had been given mixtures of grass silage and maize silage

† G = $1000 \mathrm{~g} / \mathrm{kg}$ grass; GGM = grass $670 \mathrm{~g} / \mathrm{kg}$, maize $330 \mathrm{~g} / \mathrm{kg} ; \mathrm{MMG}=$ maize $670 \mathrm{~g} / \mathrm{kg}$, grass $330 \mathrm{~g} / \mathrm{kg} ; \mathrm{M}=1000 \mathrm{~g} / \mathrm{kg}$ maize.

$\ddagger$ Approaching significance $(P<0 \cdot 1)$. 
Juniper, Browne, Fisher, Bryant, Nute and Beever

Table 8 Predicted carcass-side composition of finished steers that had been given mixtures of grass silage and maize silage

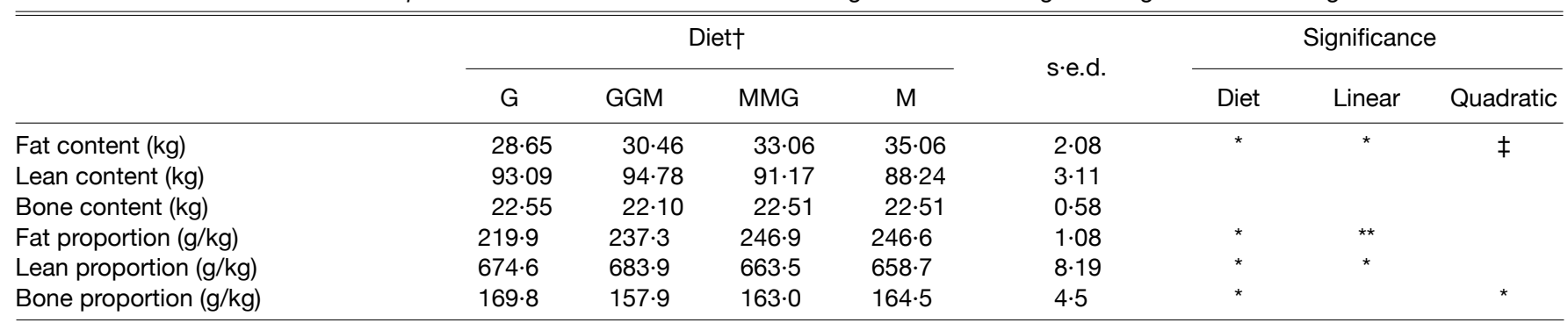

† G = $1000 \mathrm{~g} / \mathrm{kg}$ grass; GGM = grass $670 \mathrm{~g} / \mathrm{kg}$, maize $330 \mathrm{~g} / \mathrm{kg} ; \mathrm{MMG}=$ maize $670 \mathrm{~g} / \mathrm{kg}$, grass $330 \mathrm{~g} / \mathrm{kg} ; \mathrm{M}=1000 \mathrm{~g} / \mathrm{kg}$ maize.

$\ddagger$ Approaching significance $(P<0 \cdot 1)$.

are shown in Table 9. Daily gain of carcass weight improved linearly $(P<0.001)$ with ascending maize inclusion with an average of $100 \mathrm{~g} /$ day increase with each successive increment of maize silage. The relationship between starch intake and carcass gain and ME intake and carcass gain can be represented by the following equations:

$$
\begin{gathered}
\text { carcass gain }(\mathrm{kg} / \text { day })=-0.0281 x^{2}+0.1917 x+0.5929 \\
\left(R^{2}=0.643 ; \quad P<0.001\right) \\
\text { where } x=\text { total forage starch intake }(\mathrm{kg} / \text { day }) ; \\
\text { carcass gain }(\mathrm{kg} / \text { day })=-0.0002 x^{2}+0.0521 x-2.6076 \\
\left(R^{2}=0.768 ; \quad P<0.001\right) \\
\text { where } x=\mathrm{ME} \text { intake }(\mathrm{MJ} / \text { day }) .
\end{gathered}
$$

Total fat gains and fat gain per day were significantly ( $P=0.010$ and $P<0.001$, respectively) greater with increasing maize inclusion in the diet, animals offered allmaize diets depositing approximately $180 \mathrm{~g} /$ day more fat than animals offered all-grass diets. The pattern of lean gain was similar to that of fat, the rate of gain increasing significantly $(P<0.001)$ with increasing maize in the diet, with animals entirely on maize depositing approximately $150 \mathrm{~g} /$ day more than animals entirely on grass. Rate of bone gain was significantly $(P<0.05)$ greater, by approximately $33 \mathrm{~g} /$ day, in animals on all-maize than those on $670 \mathrm{~g} / \mathrm{kg}$ grass or all-grass.

The fat : lean ratio increased with increasing maize inclusion in the diets but differences were not statistically significant.

\begin{abstract}
Meat quality
The $\mathrm{pH}$ and colour values of the lean and fat tissues are shown in Table 10. Although there were no differences between diets in $\mathrm{pH}$ and colour of lean tissue, differences were found $(P<0.001)$ for fat colour. The fat colour was more yellow, indicated by the increase in hue angle, in cattle offered diets $\mathrm{G}$ and $\mathrm{GGM}$ than diets $\mathrm{M}$ and MMG. Colour saturation, the measure of colour intensity, was lower on diet $M$ than on any of the three diets containing grass $(P<0.001)$.

In the eating quality data, there were no significant interactions between diet and assessors for any of the descriptors used, indicating that the panel were homogenous in interpretation

\begin{tabular}{|c|c|c|c|c|c|c|c|c|}
\hline & \multicolumn{4}{|c|}{ Diet† } & \multirow{2}{*}{ s.e.d. } & \multicolumn{3}{|c|}{ Significance } \\
\hline & $G$ & GGM & MMG & M & & Diet & Linear & Quadratic \\
\hline Carcass gain $(\mathrm{kg}) \ddagger$ & $92 \cdot 62$ & 96.93 & $98 \cdot 25$ & $100 \cdot 03$ & $1 \cdot 93$ & $\star \star \star ~$ & 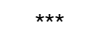 & * \\
\hline Carcass gain (kg/day) & 0.584 & $0 \cdot 709$ & $0 \cdot 797$ & $0 \cdot 872$ & 0.035 & 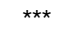 & 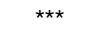 & 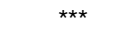 \\
\hline Efficiency of carcass gain§ & $157 \cdot 5$ & $142 \cdot 7$ & $132 \cdot 5$ & $127 \cdot 9$ & $6 \cdot 675$ & 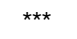 & * & $\star \star \star *$ \\
\hline Fat gain $(\mathrm{kg})$ & $37 \cdot 1$ & $43 \cdot 6$ & $47 \cdot 1$ & $47 \cdot 4$ & $3 \cdot 48$ & $\star \star$ & $\star \star$ & \\
\hline Fat gain (g/day) & $235 \cdot 0$ & $322 \cdot 0$ & $380 \cdot 0$ & $419 \cdot 0$ & $31 \cdot 3$ & 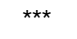 & 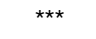 & ** \\
\hline Lean gain (kg) & $62 \cdot 32$ & $68 \cdot 18$ & $62 \cdot 12$ & $62 \cdot 49$ & $1 \cdot 859$ & & & १ \\
\hline Lean gain (g/day) & $394 \cdot 0$ & $501 \cdot 0$ & $512 \cdot 0$ & $539 \cdot 0$ & 0.03 & $\star \star \star$ & $\star \star \star ~$ & ** \\
\hline Bone gain (kg) & $13 \cdot 42$ & $10 \cdot 40$ & $12 \cdot 18$ & $13 \cdot 01$ & $1 \cdot 44$ & & & \\
\hline Bone gain (g/day) & $84 \cdot 1$ & $73 \cdot 7$ & $98 \cdot 6$ & $112 \cdot 3$ & $12 \cdot 8$ & * & १ & \\
\hline Fat:lean ratio|| & 0.611 & 0.660 & 0.792 & 0.759 & 0.080 & & * & \\
\hline
\end{tabular}
and usage of sensory attributes. The addition of maize silage to the diet did not result in any differences in eating quality, although there was a suggestion that cattle given diet GGM had the most favourable sensory scores (Table 11).
\end{abstract}

Table 9 Carcass tissue gains of finished steers that had been given mixtures of grass silage and maize silage

† G = 1000 g/kg grass; GGM = grass 670 g/kg, maize 330 g/kg; MMG = maize 670 g/kg, grass 330 g/kg; M = 1000 g/kg maize.

$\ddagger$ Initial killing-out proportion $52 \cdot 3 \mathrm{~g}$ per $100 \mathrm{~g}$.

$\S$ Intake of ME (MJ)/carcass gain $(\mathrm{kg})$.

|| Carcass daily gain of fat $(\mathrm{g})$ /daily gain of lean tissue (g)

ๆ Approaching significance $(P<0.1)$. 
Grass silage : maize silage ratios for beef steers

Table 10 Meat quality of finished steers that had been given mixtures of grass silage and maize silage

\begin{tabular}{|c|c|c|c|c|c|c|}
\hline & \multicolumn{4}{|c|}{ Diet† } & \multirow[b]{2}{*}{ s.e.d. } & \multirow[b]{2}{*}{ Significance } \\
\hline & $G$ & GGM & MMG & $M$ & & \\
\hline \multicolumn{7}{|c|}{ Lean tissue } \\
\hline Lightness & $38 \cdot 62$ & $42 \cdot 81$ & $40 \cdot 72$ & $40 \cdot 10$ & $2 \cdot 19$ & \\
\hline HUE & 23.09 & $28 \cdot 44$ & $25 \cdot 55$ & $24 \cdot 43$ & 2.91 & \\
\hline SAT & $22 \cdot 22$ & $22 \cdot 70$ & $21 \cdot 52$ & $22 \cdot 38$ & $1 \cdot 18$ & \\
\hline \multicolumn{7}{|l|}{ Fat tissueł } \\
\hline Lightness & $69 \cdot 80$ & $70 \cdot 82$ & $70 \cdot 38$ & $69 \cdot 06$ & $1 \cdot 25$ & \\
\hline HUE & $74 \cdot 20$ & $74 \cdot 60$ & $68 \cdot 46$ & $67 \cdot 03$ & $2 \cdot 22$ & 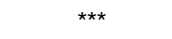 \\
\hline SAT & $15 \cdot 64$ & $16 \cdot 69$ & $16 \cdot 14$ & $12 \cdot 32$ & $1 \cdot 13$ & 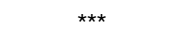 \\
\hline $\mathrm{pH}$ at $48 \mathrm{~h}$ & $5 \cdot 50$ & $5 \cdot 51$ & $5 \cdot 49$ & $5 \cdot 52$ & 0.03 & \\
\hline
\end{tabular}

† G = $1000 \mathrm{~g} / \mathrm{kg}$ grass; GGM = grass $670 \mathrm{~g} / \mathrm{kg}$, maize $330 \mathrm{~g} / \mathrm{kg} ; \mathrm{MMG}=$ maize $670 \mathrm{~g} / \mathrm{kg}$, grass $330 \mathrm{~g} / \mathrm{kg} ; \mathrm{M}=1000 \mathrm{~g} / \mathrm{kg}$ maize.

$\ddagger \mathrm{HUE}=$ hue angle, a measure of colour; SAT = colour saturation, a measure of colour intensity.

\section{Discussion}

The maize silage used in this experiment was of good quality, as indicated by its DM and starch content. The grass silage, although typical of the type of forage given to many beef cattle, was of lower nutritional quality than the maize silage. Chemical composition of both grass silage and maize silage is known to affect their intake characteristics (Steen et al., 1998; Wilkinson et al., 1978; de Brabander et al., 1990) and thus it is perhaps predictable that the substitution of grass silage by maize silage would cause a positive effect on voluntary forage intake and cattle performance. However, there are several examples in the literature where maize silage of lower organic matter digestibility than grass silage has stimulated higher voluntary forage intake (Hameleers, 1998; O'Mara et al., 1998; Mulligan et al., 1999) although this is generally accompanied by little or no effect on milk yield in dairy cows.

Completely replacing grass silage with maize silage increased forage DM intake by proportionately $0 \cdot 23$. Findings from other studies have indicated that intake of maize silage by beef cattle is proportionately 0.20 to 0.36 higher than that of grass silage depending on the amount of supplementary food given (Aston and Tayler, 1980; McCabe et al., 1995). The linear intake response to forage substitution observed in the current experiment has been reported previously with dairy cows (Izumi et al., 1982; Phipps et al., 1995; O'Mara et al., 1998). However it is probable that the linearity of the relationship was dependent on achieving satisfactory mixing of the two forages since Syed and Leaver (1999) reported significantly increased forage intake of mixed grass silage and maize silage diets compared with feeding the two forages unmixed. Thus, the response to feeding grass silage and maize silage together may have been different if the forages had been offered layered one on top of the other or in different food troughs as opposed to being mixed.

Very few forage mixture studies involving beef cattle have been conducted yet similar intake and production responses to those of the present experiment were reported by McCabe et al. (1995). Voluntary forage intake of finishing beef steers given a moderate quality grass silage and $4 \mathrm{~kg}$ of concentrates increased by $1.3 \mathrm{~kg}$ DM per day when $50 \mathrm{~g}$ per $100 \mathrm{~g}$ of forage DM was replaced by maize silage of similar DM digestibility but containing little starch (2 g/kg DM). Intake further increased by $0.6 \mathrm{~kg} /$ day when all the grass silage was replaced by maize silage. The respective rates of LWG were much lower than recorded in the current work at $0.76,0.85$ and $0.92 \mathrm{~kg} /$ day; this reflects the late stage of maturity of the animals in the experiment which were over $600 \mathrm{~kg} \mathrm{LW}$ at the start of the experiment. Completely replacing grass silage with maize silage in the present experiment increased rate of LWG by proportionately 0.37 . Similar responses have been reported elsewhere but the relative food quality of the two forages is likely to influence the differential in performance. Canadian studies have shown that replacing grass silage with maize silage can increase rate of LWG by between proportionately 0.60 and 1.30 (Forrest, 1982 : Forrest and Vanderstoep, 1985). However work in Britain suggests that

Table 11 Meat eating quality of finished steers that had been given mixtures of grass silage and maize silage

\begin{tabular}{|c|c|c|c|c|c|}
\hline & \multicolumn{4}{|c|}{ Diet† } & \multirow[b]{2}{*}{ s.e.d. } \\
\hline & $\mathrm{G}$ & GGM & MMG & $M$ & \\
\hline Toughness & $49 \cdot 5$ & $44 \cdot 5$ & $49 \cdot 5$ & $49 \cdot 1$ & 2.97 \\
\hline Juiciness & 44.9 & $45 \cdot 8$ & $45 \cdot 4$ & 42.9 & $2 \cdot 35$ \\
\hline Beef flavour & $39 \cdot 8$ & $40 \cdot 5$ & $37 \cdot 8$ & $37 \cdot 1$ & 1.92 \\
\hline Fatty/greasy & $19 \cdot 1$ & $16 \cdot 7$ & $18 \cdot 4$ & $15 \cdot 5$ & $1 \cdot 73$ \\
\hline Livery & $9 \cdot 0$ & $9 \cdot 2$ & $10 \cdot 0$ & $8 \cdot 5$ & $1 \cdot 74$ \\
\hline Metallic & $3 \cdot 8$ & 4.9 & $3 \cdot 2$ & $4 \cdot 1$ & 0.94 \\
\hline Bitter & $3 \cdot 8$ & $2 \cdot 0$ & $3 \cdot 4$ & $3 \cdot 4$ & 0.83 \\
\hline Overall liking & $24 \cdot 9$ & $29 \cdot 8$ & $26 \cdot 9$ & $25 \cdot 5$ & $2 \cdot 12$ \\
\hline
\end{tabular}

were no significant treatment effects $(P>0.05)$. 


\section{Juniper, Browne, Fisher, Bryant, Nute and Beever}

increases of between proportionately0.20 and 0.35 would be expected (Aston and Tayler, 1980; McCabe et al., 1995).

Likewise, estimated carcass gains increased with maize silage inclusion, but at a faster rate. Due to the positive effect of maize silage on killing-out proportion as well as growth rate, carcass gains of cattle on diet $M$ were proportionately 0.50 higher than for cattle given diet G. McCabe et al. (1995) reported that at the same level of concentrate feeding a maize-silage-based diet produced $100 \mathrm{~g}$ carcass gain per day more than a grass-silage-based diet. This compares to an increase of over $250 \mathrm{~g}$ carcass gain per day in the present experiment, reflecting the much higher starch content of the silage as well as the greater growth potential of the cattle used. Although the concentrates offered with the grasssilage-based diets were higher in wheat than those offered with diets predominantly containing maize silage, the high starch content of maize silage resulted in cattle given diet $M$ consuming an extra $1.87 \mathrm{~kg} /$ day of starch, over 0.80 of which was derived from forage. In fact starch comprised 0.29 of total DM intake in diet M compared with 0.11 in diet G.

The killing-out proportion of cattle given maize silage was $1.6 \mathrm{~g}$ per $100 \mathrm{~g}$ greater than those given grass silage and equated to each animal yielding an additional $9 \mathrm{~kg}$ of carcass, assuming an equal slaughter LW of $560 \mathrm{~kg}$. Unlike this study, other work comparing grass silage and maize silage has failed to record differences in killing-out proportion (Aston and Tayler, 1980; McCabe et al., 1995). This may be due to the large extent to which this proportion is influenced by carcass trimming practices.

As maize silage replaced grass silage, increased rates of fat deposition were noted, which were reflected in both increased fat content of the whole carcass and the size and rate of internal fat deposition in the kidney knob fat and the cod fat depots. Fat to lean ratios of carcass gain increased with maize silage inclusion from a value of 0.611 in the entirely grass-silage-based diet to 0.759 where maize silage was the sole forage component. Since no fat was trimmed before the carcasses were weighed this could partially account for the difference in killing-out proportion, whilst differences in gut fill between diets could also be involved. Forrest (1982) reported that steers finished on maize silage had significantly more dissectible fat at slaughter than cattle on grass silage and more marbling (intramuscular) fat. These cattle also had a significantly higher killing-out proportion than those given grass silage. Conversely, subsequent work by the same researcher (Forrest and Vanderstoep, 1985) failed to show differences in killing-out proportion between silages despite cattle on maize silage producing fatter carcasses. McCabe et al. (1995) observed no difference in fat score between cattle given maize and those given grass silage, although in this instance the maize silage contained virtually no starch. In the current study, there were no significant differences in carcass fat scores although the trend, using the 15-point range, was for fatness to be higher in the cattle on the two higher levels of maize. The lack of a significant difference probably reflects the fact that there was only a small range $(27.0 \mathrm{~g} / \mathrm{kg})$ in carcass fat proportion across diets, less than that between the adjacent fat classes 3 and $4 \mathrm{~L}(36 \mathrm{~g} / \mathrm{kg})$ (Kempster et al., 1986).

Despite the increases in fat deposition, the positive effect of maize silage on total DM intake and therefore the improvement in growth rate was sufficient to significantly increase the efficiency with which silage was converted to LWG. In fact all diets containing maize silage resulted in higher food conversion efficiency than diet $\mathrm{G}$, which suggests that even substituting $33 \mathrm{~g}$ per $100 \mathrm{~g}$ of grass silage with maize silage will be beneficial to beef cattle producers. However, when efficiency of ME utilization was calculated in terms of MJ of tissue retained in the carcass for each $\mathrm{MJ}$ input of ME net of maintenance, efficiency improved with maize inclusion in the diet from $\mathrm{G}$ to MMG by over proportionately 0.10 before declining again to $M$ (Table 12). Unlike the present experiment Aston and Tayler (1980) found no differences in efficiency of food use between grass silage and maize silage diets when supplemented with barley, but noted a tendency for grass silage food efficiency to be lower than maize silage without cereal supplementation.

Table 12 Metabolizable energy (ME) utilization of finishing beef steers given mixtures of grass silage and maize silage

\begin{tabular}{|c|c|c|c|c|}
\hline & \multicolumn{4}{|c|}{ Diet† } \\
\hline & G & GGM & MMG & M \\
\hline \multicolumn{5}{|l|}{ Input } \\
\hline Gross energy (GE) intake (MJ) & $158 \cdot 21$ & $167 \cdot 08$ & $177 \cdot 17$ & $182 \cdot 99$ \\
\hline ME intake $(\mathrm{MJ}) \ddagger$ & $92 \cdot 62$ & $98 \cdot 72$ & $106 \cdot 03$ & 111.56 \\
\hline ME/GE (qm) & 0.59 & 0.59 & $0 \cdot 60$ & 0.61 \\
\hline \multicolumn{5}{|l|}{ Output } \\
\hline Maintenance (MJ) & $50 \cdot 34$ & $50 \cdot 34$ & $50 \cdot 10$ & $49 \cdot 85$ \\
\hline Efficiency of maintenance $\left(\mathrm{k}_{\mathrm{m}}\right) \S$ & $0 \cdot 7095$ & $0 \cdot 7095$ & $0 \cdot 7130$ & $0 \cdot 7165$ \\
\hline Energy content of lean (MJ)\| & $8 \cdot 748$ & $10 \cdot 136$ & $11 \cdot 607$ & $12 \cdot 554$ \\
\hline Energy content of fat $(\mathrm{MJ}) \|$ & $8 \cdot 641$ & $11 \cdot 327$ & $14 \cdot 044$ & $14 \cdot 781$ \\
\hline Comparative efficiency of gain & $0 \cdot 411$ & $0 \cdot 444$ & $0 \cdot 458$ & $0 \cdot 443$ \\
\hline
\end{tabular}

† G = $1000 \mathrm{~g} / \mathrm{kg}$ grass; GGM = grass $670 \mathrm{~g} / \mathrm{kg}$, maize $330 \mathrm{~g} / \mathrm{kg} ; \mathrm{MMG}=$ maize $670 \mathrm{~g} / \mathrm{kg}$, grass $330 \mathrm{~g} / \mathrm{kg} ; \mathrm{M}=1000 \mathrm{~g} / \mathrm{kg}$ maize.

‡ Browne (2000). Estimated ME intake based on maize silage ME calculated from neutral-detergent cellulose (AFRC, 1995). Grass silage ME calculated from OMD predicted using NIR spectroscopy (ADAS/DANI/SAC/UKASTA, 1993).

$\S \mathrm{k}_{\mathrm{m}}=0.35 \mathrm{q}_{\mathrm{m}}+0.503$ (AFRC, 1995).

\| Energy content of lean tissue $=23.6 \mathrm{~kJ} / \mathrm{g}$ (McDonald et al., 1995); and energy of content fat tissue $=39.3 \mathrm{~kJ} / \mathrm{g}$ (McDonald et al., 1995).

ๆी [Energy content of lean (MJ) + energy content of fat (MJ)]/[ME intake (MJ) - maintenance (MJ)]. 


\section{Grass silage : maize silage ratios for beef steers}

The positive effect of maize silage on growth rate was due in part to the greater DM intake of these cattle, which was associated with increased ME and CP intakes. Energy intake increased as a direct result of the higher energy concentration and intake of maize silage relative to grass silage. However, the protein content of maize silage was lower than grass silage resulting in CP supply from forage being least in diet $M$ and greatest in diet $G$. The additional protein required to maintain all four diets as being isonitrogenous was supplied primarily from soya-bean meal and rapeseed meal in the concentrates, thus the ratio of forage $N$ to supplementary $\mathrm{N}$ reduced from $1 \cdot 7: 1$ in diet $\mathrm{G}$ to $0 \cdot 89: 1$ in diet M. Furthermore, the calculated metabolizable protein (MP) : ME ratios declined with ascending maize silage inclusion from $10.4 \mathrm{~g} / \mathrm{MJ}$ where grass was the sole forage to $6.6 \mathrm{~g} / \mathrm{MJ}$ when maize silage comprised the entire forage fraction. Consequently, the supply of energy substrate may well have exceeded the available MP supply for tissue synthesis, resulting in the increased ratios of fat to lean in the carcass gain of animals on maize-silage-based diets. Possibly an increase in MP supply in maize-silage diets may improve lean deposition and reduce the level of fatness in the carcass.

Replacing grass silage with maize silage did not result in any significant differences in meat quality as neither lean colour nor $\mathrm{pH}$ were different between dietary treatments, although the fat colour was more yellow in the group on grass silage. This is consistent with the findings of Daly et al. (1999) who also reported that neither meat colour nor $\mathrm{pH}$ were influenced when steers received either pasture-based or maize-based diets but fat colour was more yellow in the group on pasture. The increase in fat colour is probably the result of the increased carotenoid content of grass as Knight et al. (1998) reported that carotenoid concentration in fat accounted for 0.60 of the variation in chromameter parameters for colour $\left(L^{*}, a^{*}\right.$ and $\left.b^{*}\right)$. Increased marbling (intramuscular fat) has often been associated with improved meat eating quality (Tatum et al., 1982; Jones et al., 1991; Wheeler et al., 1994). In this experiment, there were no differences in toughness or juiciness between dietary treatments, again probably because the range in fatness was small. In contrast, HovingBolink et al. (1999) and Kogel et al. (1998) did report that animals on maize silage, when compared with animals that had received diets from other forage sources, had a more favourable sensory evaluation, although it should be noted that these two studies incorporated different breeds and utilized heifers whereas the study detailed here used Simmental cross Holstein-Friesian steers. Most of the flavour descriptors showed no consistent trend across diets; only beef flavour exhibited some evidence of a dietary effect in that it was more pronounced in the two groups eating most grass. The difference was, however, non-significant.

Both McCabe et al. (1995) and Aston and Tayler (1980) reported that at least an extra $2 \mathrm{~kg}$ of concentrates were required to enable cattle on grass silage to achieve comparable rates of LWG to those on maize silage. Therefore, maize silage offers the potential to reduce the amount of concentrates given to a finishing beef animal or reduce the duration of the finishing period. However, it is likely that the response will depend on the relative nutritive value of the silages offered. In this experiment, replacing grass silage with maize silage shortened the finishing period by 40 days, assuming a constant start and slaughter weight for all cattle. Alternatively, maintaining the length of the finishing period would increase carcass weights, but this would be associated with an increase in carcass fatness that would be unacceptable in most grading systems. Further work is required to establish if increasing the MP supply may increase lean tissue synthesis at the expense of fat deposition.

\section{Acknowledgements}

This experiment was part of a project funded by DEFRA, Meat and Livestock Commission, J. Bibby Agriculture, Tesco and the Maize Growers Association. The authors would also like to thank $\mathrm{Mr}$ D. Cox, Mr J. Jenkins and Miss S. Gore for technical support in conducting the study.

\section{References}

ADAS/DANI/SAC/UKASTA. 1993. The NIRS regression equations for silage evaluation. Press release, UKASTA, London.

Agricultural and Food Research Council. 1995. Energy and protein requirements of ruminants. CAB International, Wallingford.

Aston, K. and Tayler, J. C. 1980. Effects of supplementing maize and grass silages with barley, and maize silage with urea or ammonia, on the intake and performance of fattening bulls. Animal Production 31: 243-250.

Bergstrom, P. L. and Williams, D. R. 1980. Anatomical jointing, tissue separation and weight recording: EEC standard method for beef. Commission of the European Communities, EUR 6878 EN.

Boer, H. de, Dumont, B. L., Pomeroy, R. W. and Weniger, J. H. 1974. Manual on EAAP methods for the assessment of carcass characteristics in cattle. Livestock Production Science 1: 151-164.

Brabander, D. L. de, Boever, J. L. de and Buysse, F. X. 1990. The quality and utilisation of maize silage for dairy cattle. Proceedings of the second annual conference of the Maize Growers Association, Berkshire College of Agriculture.

British Standards Institution. 1993. Assessors for sensory analysis. Part 1. Guide to the selection, training and monitoring of selected assessors. BS7667. British Standards Institution, London.

Broadbent, P. J., Mclntosh, J. A. R. and Spence, A. 1970. The evaluation of a device for feeding group housed animals individually. Animal Production 12: 245-252.

Browne, E. M. 2000. Maize silage-based diets for finishing beef cattle. Ph. D. thesis, University of Reading.

Browne, E. M., Bryant, M. J., Beever, D. E. and Thorp, C. L. 1998. Effect of forage maize harvested at different stages of maturity on feed intake and performance by growing beef cattle. Proceedings of the British Society of Animal Science, 1998, p. 148.

Bryan, J. G. E. 1990. The potential for beef production from forage crops. In Milk and meat from forage crops (ed. G. E. Pollott), British Grassland Society occasional symposium no. 24, pp. 252-254.

Daly, C. C., Young, O. A., Graafhuis, A. E., Moorhead, S. M. and Easton, H. S. 1999. Some effects of diet on beef meat and fat attributes. New Zealand Journal of Agricultural Research 42: 279-287.

European Economic Community. 1981. Council regulation (EEC) no. $1208 / 81$ of 28 April 1981 determining the Community scale for the classification of carcasses from adult bovine animals. EEC Official journal no. L123/3 (7.5.81), pp. 191-193.

Forrest, R. J. 1982. A comparison of the growth and carcass characteristics of steers reared on pasture and finished for varying periods on corn or grass silage. Canadian Journal of Animal Science 62: 769-772.

Forrest, R. J. and Vanderstoep, J. 1985. A comparison of grass and corn silages for finishing steers. Canadian Journal of Animal Science 65: 769-772. 


\section{Juniper, Browne, Fisher, Bryant, Nute and Beever}

Gerring, J. 1990. Maize: a farmer's experience. In Milk and meat from forage crops (ed. G. E. Pollott), British Grassland Society occasional symposium no. 24, pp. 121-126.

Hameleers, A. 1998. The effects of the inclusion of either maize silage, fermented whole crop wheat or urea-treated whole crop wheat in a diet based on high-quality grass silage on the performance of dairy cows. Grass and Forage Science 53: 157-163.

Honikel, K. O. 1998. Reference methods for the assessment of physical characteristics of meat. Meat Science 49: 447-457.

Hoving-Bolink, A. H., Hanekamp, W. J. A. and Walstra, P. 1999. Effects of diet on carcass, meat and eating quality of once-bred Piemontese x Friesian heifers. Livestock Production Science 57: 267-272.

Izumi, Y., Kurosawa, H., Ogura, N., Ishida, S. and Onue, S. 1982. Effect of feeding various levels of grass silage and corn silage to lactating dairy cows. Japanese Journal of Zootechnical Science 53: 686-691.

Jones, S. D. M., Jeremiah, L. E., Tong, A. K. W., Lutz, S. and Robertson, W. M. 1991. The effect of marbling level, electrical stimulation, and post-mortem aging on the cooking and palatability properties of rib-eye stakes. Canadian Journal of Animal Science 71: 1037-1043.

Kempster, A. J., Cook, G. L. and Grantley-Smith, M. 1986. National estimates of the body composition of British cattle, sheep and pigs with special reference to trends in fatness: a review. Meat Science 17: 107-138.

Knight, T. W., Death, A. F., Boom, C. J. and Litherland, A. J. 1998. The relationship between carotenoid concentration and fat colour in beef carcasses. Proceedings of the New Zealand Society of Animal Production 58: 256-258.

Kogel, V. J., Augustini, C., Pickl, M. and Edelmann, P. 1998. Influence of grass silage, meadow hay and corn silage on meat quality of heifers. Züchtungskunde 70: 185-195.

McCabe, N. H., O'Mara, F. P. and Caffery, P. J. 1995. Evaluation of maize silage in the diet of finishing steers. Animal Science 60: 554A.

McDonald, P., Edwards, R. A., Greenhalgh, J. F. D. and Morgan, C. A. 1995. Animal nutrition, fifth edition. Pearson Education Ltd, Harlow, UK.

MacRae, J. C. and Armstrong, D. G. 1968. Enzyme method for determination of $\alpha$-linked glucose polymers in biological materials. Journal of the Science of Food and Agriculture 19: 578-581.

Ministry of Agriculture, Fisheries and Food. 1982. The feedingstuffs (sampling and analysis) regulatory instrument no. 1144. Her Majesty's Stationery Office, London.

Ministry of Agriculture, Fisheries and Food. 1986. The analysis of agricultural materials. MAFF reference book 427. Her Majesty's Stationery Office, London.

Ministry of Agriculture, Fisheries and Food. 1992. UK tables of feed composition and nutritive value for ruminants, second edition. Chalfont Publications, Canterbury.

Ministry of Agriculture, Fisheries and Food. 1993. Prediction of the energy values of compound feeding stuffs for farm animals. MAFF Publications, London.

Mulligan, F. J., O'Mara, F. P., Rath, M., Caffery, P. J., Callan, J. and Flynn, B. 1999. Factors affecting the feeding value of maize and grass silage in late lactation dairy cows. Proceedings of the British Society of Animal Science, 1999, p. 79.

Nix, J. 2003. Farm management pocketbook (34th edition). Wye College, Ashford.

O'Mara, F. P., Fitzgerald, S., Murphy, J. J. and Rath, M. 1998. The effect on milk production of replacing grass silage with maize silage in the diet of dairy cows. Livestock Production Science 55: 79-87.

Pahl, H., Steinhauser, H. and Heissenhuber, A. 1987. The cultivation of selected animal feed stuffs (maize and perennial ryegrass, whole plant silage and maize husks), and the economics of their use in fattening bulls. Berichte uber Landwirtschaft 65: 629-670.

Phipps, R. H., Sutton, J. D. and Jones, B. A. 1995. Forage mixtures for dairy cows: the effect on dry-matter intake and milk production of incorporating either fermented or urea-treated whole-crop wheat, brewers' grains, fodder beet or maize silage into diets based on grass silage. Animal Science 61: 491-496.

Phipps, R. H., Weller, R. F. and Rook, A. J. 1992. Forage mixtures for dairy cows: the effect on dry matter intake and milk production of incorporating different proportions of maize silage into diets based on grass silage of differing energy value. Journal of Agricultural Science, Cambridge 118: 379-382.

Porter, M. G., Patterson, D. C., Steen, R. J. W. and Gordon, F. J. 1984. Determination of dry matter and gross energy of grass silage. Proceedings of the seventh silage conference on silage production and utilisation, Belfast (ed. F. J. Gordon and E. F. Unsworth), pp. 89-90.

Steen, R. W. J., Gordon, F. J., Dawson, L. E. R., Park, R. S., Mayne, C. S., Agnew, R. E., Kilpatrick, D. J. and Porter, M. G. 1998. Factors affecting the intake of grass silage by cattle and prediction of silage intake. Animal Science 66: 115-127.

Syed, J. S. and Leaver, J. D. 1999. Effect on milk production in dairy cows of feeding grass silage and maize silage as a mixture, or separately within days, or on alternate days, with low or high protein supplements. Proceedings of the British Society of Animal Science, 1999, p. 202.

Tatum, J. D., Smith, G. C. and Carpenter, Z. L. 1982. Interrelationships between marbling, subcutaneous fat thickness and cooked beef palatability. Journal of Animal Science 54: 777-784.

Vadiveloo, J. and Holmes, W. 1979. The effects of cereal supplementation of grass and maize silages. Grass and Forge Science 34: 319-321.

Vatansever, L., Kurt, E., Enser, M., Nute, G. R., Scollan, N. D., Wood, J. D. and Richardson, R. I. 2000. Shelf life and eating quality of beef from cattle of different breeds given diets differing in $\mathrm{n}-3$ polyunsaturated fatty acid composition. Animal Science 71: 471-482.

Wheeler, T. L., Cundiff, L. V. and Koch, K. M. 1994. Effect of marbling degree on beef palatability in Bos taurus and Bos indicus cattle. Journal of Animal Science 72: 3145-3151.

Wilkinson, J. M., Penning, I. M. and Osbourn, D. F. 1978. Effect of stage of harvest and fineness of chopping on the voluntary intake and digestibility of maize silage by young beef cattle. Animal Production 26: 143-150.

(Received 21 July 2004 - Accepted 16 February 2005) 